\title{
Review
}

\section{Genetics and biology of vitamin D receptor polymorphisms}

\author{
André G. Uitterlinden*, Yue Fang, Joyce B.J. van Meurs, Huibert A.P. Pols, \\ Johannes P.T.M. van Leeuwen
}

Genetic Laboratory, Room Ee575, Department of Internal Medicine, Erasmus MC, Dr. Molewaterplein 50, PO Box 1738, NL-3000 DR Rotterdam, The Netherlands

Received 28 February 2004; received in revised form 26 April 2004; accepted 17 May 2004

Available online 21 July 2004

Received by A.J. van Wijnen

\begin{abstract}
The vitamin D endocrine system is involved in a wide variety of biological processes including bone metabolism, modulation of the immune response, and regulation of cell proliferation and differentiation. Variations in this endocrine system have, thus, been linked to several common diseases, including osteoarthritis (OA), diabetes, cancer, cardiovascular disease, and tuberculosis. Evidence to support this pleiotropic character of vitamin D has included epidemiological studies on circulating vitamin D hormone levels, but also genetic epidemiological studies. Genetic studies provide excellent opportunities to link molecular insights with epidemiological data and have therefore gained much interest. DNA sequence variations, which occur frequently in the population, are referred to as "polymorphisms" and can have modest and subtle but true biological effects. Their abundance in the human genome as well as their high frequencies in the human population have made them targets to explain variation in risk of common diseases. Recent studies have indicated many polymorphisms to exist in the vitamin D receptor (VDR) gene, but the influence of VDR gene polymorphisms on VDR protein function and signaling is largely unknown. So far, three adjacent restriction fragment length polymorphisms for BsmI, ApaI, and TaqI, respectively, at the $3^{\prime}$ end of the VDR gene have been the most frequently studied. Because these polymorphisms are probably nonfunctional, linkage disequilibrium with one or more truly functional polymorphisms elsewhere in the VDR gene is assumed to explain the associations observed. Research is therefore focussed on documenting additional polymorphisms across the VDR gene to verify this hypothesis and on trying to understand the functional consequences of the variations. Substantial progress has been made that will deepen our understanding of variability in the vitamin D endocrine system and might find applications in risk assessment of disease and in predicting response-to-treatment.
\end{abstract}

(C) 2004 Elsevier B.V. All rights reserved.

Keywords: Polymorphism; VDR; Complex trait; Osteoporosis; SNP

\section{Introduction}

The secosteroid hormone vitamin $\mathrm{D}$, its receptor (VDR), and the metabolizing enzymes involved in the

Abbreviations: BMD, bone mineral density; COL2A1, collagen type II alpha 1; FISH, fluorescent in situ hybridization; HRT, hormone replacement therapy; IL2, interleukin 2; LD, linkage disequilibrium; OA, osteoarthritis; PBMC, peripheral blood mononuclear cell; RFLP, restriction fragment length polymorphism; SD, standard deviation; SNP, single/simple nucleotide polymorphism; STS, sequence-tagged site; TDT, transition disequilibrium testing; UTR, untranslated region; VDR, vitamin D receptor; VDRE, vitamin D responsive elements; VNTR, variable number of tandem repeats.

* Corresponding author. Tel.: +31-10-4087573; fax: +31-10-4635430

E-mail address: a.g.uitterlinden@erasmusmc.nl (A.G. Uitterlinden). formation of the biologically active form of the hormone together are major players in the vitamin D endocrine system. This system plays an important role in skeletal metabolism, including intestinal calcium absorption, but has also been shown to play an important role in other metabolic pathways, such as those involved in the immune response and cancer (Haussler et al., 1998). In the immune system, for example, vitamin D promotes monocyte differentiation and inhibits lymphocyte proliferation and secretion of cytokines, such as interleukin 2 (IL2), interferon- $\gamma$, and IL12. In several different types of cancer cells, vitamin $\mathrm{D}$ has been shown to have antiproliferative effects.

At the same time, it is also widely known that large interindividual differences exist. One approach to under- 
stand interindividual differences in the vitamin $\mathrm{D}$ endocrine system is to study the influence of variations in the DNA sequence of important proteins of this system. For example, deleterious mutations in the VDR gene cause 1,25-dihydroxyvitamin $\mathrm{D}$ resistant rickets, a rare monogenetic disease. More subtle sequence variations (polymorphisms) in the VDR gene occur much more frequently in the population, but they have not been systematically analysed and their effects on VDR function are poorly understood. Their influence on the vitamin D endocrine system is currently under scrutiny in relation to a number of so-called complex diseases and traits, such as osteoporosis. This so-called candidate gene approach in the genetic dissection of complex traits is currently gaining increased importance over genome search approaches using linkage analysis (Risch and Merikangas, 1996).

The interpretation of polymorphic variations in the VDR gene is severely hindered by the fact that until now, only few polymorphisms in this large gene have been studied, and that most of these are anonymous restriction fragment length polymorphisms (RFLP), i.e., have an unknown functional effect. One expects them to be linked to truly functional polymorphisms elsewhere in the VDR gene [or in nearby gene(s)] which can then explain the associations observed. Thus, to understand the mechanisms underlying the associations, one has to analyse the genomic organization of the VDR locus, to identify which genes are present in the chromosomal area, to categorize all relevant VDR polymorphisms, to determine the haplotypes across the gene, to determine their relationship with the RFLP markers used so far, andfinally - to perform association analyses with relevant phenotypic endpoints such as disease.

Below we present a more detailed description of the genomic organization of the VDR gene including discussion on polymorphisms, linkage disequilibrium, and haplotypes. Historically speaking, studies of VDR polymorphisms in relation to bone endpoints, including osteoporosis in particular, have received most attention, while the analysis of VDR polymorphisms in relation to other diseases, including breast and prostate cancer and immunerelated disorders, has reached the literature somewhat later on. This allows studies on associations with bone endpoints to be compared to a certain extent and to illustrate some of the difficulties in interpreting the results. This is much less possible for VDR polymorphism studies in relation to other disease endpoints, although similar interpretation problems exist. Essentially, these interpretation problems find their origin in the lack of knowledge on which polymorphisms are present in the VDR gene area and not knowing what the functional relevance is of these polymorphisms. Therefore, most attention in this review will be focussed on these aspects rather than providing an exhaustive review on which studies have found their way to the literature on VDR polymorphisms and association with one or other disease endpoint.

\section{Genomic structure of the $12 Q 13$ locus}

After cloning the human VDR cDNA in 1988 by Baker et al. (1988), it took almost 10 years before major parts of the genomic structure of the human VDR gene became clear as described by Miyamoto et al. (1997). All of this happened of course before the Human Genome Project became to bear fruit in the form of easily accessible databases where genomic sequences can be found. Yet, these databases are still not complete and for particular genes, efforts have to be made to determine their genomic structure. The location of the VDR gene on the physical map of chromosome 12 was elucidated first roughly by linkage mapping by Labuda et al. (1992) and later on somewhat more refined by fluorescent in situ hybridization (FISH) and radiation hybrid mapping by Taymans et al. (1999). However, these studies defined the position of the VDR gene in very general terms with a resolution of $>100 \mathrm{~kb}$, and this is insufficient for understanding the role of VDR polymorphisms in disease. The major reason to know the exact gene content and distances of this area is coming from the genetic association studies. Since mostly anonymous polymorphisms have been used, one of the explanations of the associations observed is that not the VDR gene itself is explaining the association but another nearby gene. It is therefore important to know which genes are also present in the area, how close they are to the VDR gene and, thus, how likely it is that these other genes are explaining the associations.

We have therefore extended these physical mapping studies of the VDR gene to create a high-resolution physical map of the chromosomal 12q13 region in which the VDR gene is located. For this, we applied thorough analysis of all available databases with genomic sequences, pulsed field gel electrophoresis to determine the exact location, and order of the VDR gene and its neighbouring genes. Our analysis of the genomic organization of the VDR locus at chromosome 12q13.1 has shown that the VDR gene itself is quite large (just over $100 \mathrm{~kb}$; see Fig. 1; van Meurs et al., unpublished), has an extensive promoter region capable of generating multiple tissue-specific transcripts (Crofts et al., 1998), and lies just downstream from the collagen type II alpha 1 (COL2A1) gene (Huang et al., 1991; Takahashi et al., 1990).

On the genetic map ${ }^{1}$, both VDR and COL2A1 genes are mapped around position $63 \mathrm{cM}$, between the markers D12S85 and D12S368. The radiation hybrid map ${ }^{2}$ confirms the close conjunction of the two genes since both genes are mapped close to the 210 centiRod position. The sequencetagged site (STS)-based contig map ${ }^{3}$ shows that VDR and

\footnotetext{
1 http://www.marshfieldclinic.org/research/genetics.

2 http://www.ncbi.nlm.nih.gov/mapview/maps.cgi?ORG =hum\& MAPS $=$ ideogr,loc $\&$ VERBOSE $=$ ON\&CHR $=12$.

3 http://www.ncbi.nih.gov/mapview/maps.cgi?taxid $=9606 \& \mathrm{chr}=12 \&$ maps $=\mathrm{gb} 4, \mathrm{sts} \& \mathrm{SET}=\mathrm{CLOSE} \& \mathrm{LINKS}=\mathrm{ON} \& \mathrm{VERBOSE}=\mathrm{ON} \&$ $\mathrm{ZOOM}=10 \&$ sts $=5822$.
} 


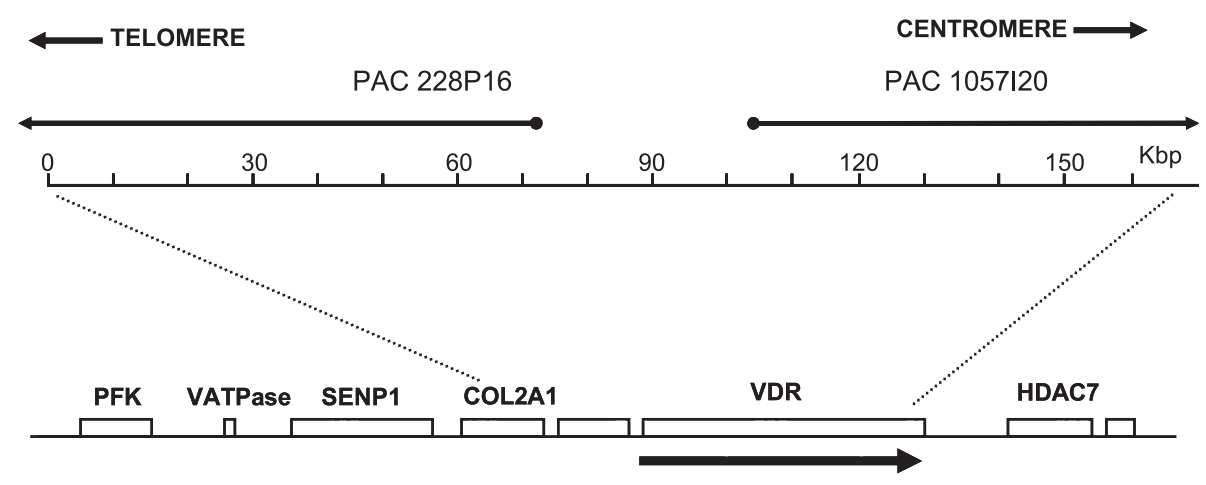

Fig. 1. Genomic structure of the VDR-COL2A1 locus on chromosome 12q13.1 and detailed physical map position of the PAC clones $228 \mathrm{P} 16$ and $1057 \mathrm{I} 20$. The arrow indicates direction of transcription of the VDR gene. PFK = phosphofructokinase; VATPase = Vacuolar ATPase; SENP1 = sentrin/SUMO-specific protease; HDAC7 = histone deacetylase 7 .

COL2A1 are located on two separate PAC clones (P1057I20 and P228P16, respectively). Fig. 1 shows a compilation of all the information from the databases and our own results with respect to the VDR-COL2A1 locus combined with information of the genomic organization of the VDR gene. Recently, most of this information can also be found in the draft of the human genome ${ }^{4}$, but up to now, a gap in the sequence was still present between COL2A1 and VDR. Fig. 1 shows the completed physical map of the region surrounding VDR. Besides already identified genes [phosphofructokinase (PFKM), sentrin/SUMO specific protease (SENP1), and histone deacetylase (HDAC7)], also some so far unknown genes were identified (e.g., a gene-like structure MGC5576; information available at http:// www.ncbi.nlm.nih.gov/LocusLink/LocRpt.cgi?/=79022).

From these results, it appears that, in the absence of evidence for the role of the other genes in the area in, for example, bone metabolism, the VDR gene is the obvious candidate gene to explain the associations found. The next step is to determine the polymorphisms in the relevant areas and determine how they are interacting with each other in genetic terms and in functional terms.

\section{VDR polymorphisms}

Information on the existence of VDR polymorphisms so far has come from analysis of only limited areas in the gene and by using rather insensitive techniques to find polymorphisms, such as screening with different restriction enzymes for polymorphic banding patterns in Southern blot hybridization experiments. Examples of this include the ApaI(Faraco et al., 1989), EcoRV- (Morrison et al., 1992), BsmI(Morrison et al., 1992), TaqI- (Morrison et al., 1994), and Tru9I- (Ye et al., 2000) restriction fragment length polymorphisms (RFLPs) discovered at the $3^{\prime}$ end of the VDR gene by this approach in the early 1990s. In Fig. 2, a number of the currently known VDR polymorphisms are depicted.

\footnotetext{
4 http://genome.ucsc.edu
}

A special case in this respect is presented by the discovery of the so-called FokI RFLP. Upon comparison of the original Baker sequence of the VDR cDNA (Baker et al., 1988), two potential translation initiation start sites (ATG) were observed and subsequent sequence comparisons have shown that a $\mathrm{T}$ to $\mathrm{C}$ polymorphism exists (ATG to ACG) at the first potential start site (Gross et al., 1996; Saijo et al., 1991; Sturzenbecker et al., 1994). This polymorphism, also referred to as the start codon polymorphism or $\mathrm{SCP}$, was later on defined using the FokI restriction enzyme in an RFLP test (Arai et al., 1997). Thus, two protein variants can exist corresponding to the two available start sites: a long version of the VDR protein (the T-allele or the "f" allele; and also referred to as the M1 form, i.e., the methionine at first position) and a protein shortened by three amino acids (the $\mathrm{C}$-allele detected as the "F" allele; also referred to as the M4 form, i.e., the methionine at fourth position). Hitherto, this is the only known protein polymorphism in the VDR gene.

A more informative approach to find polymorphisms is to simply determine the base pair sequence of the same part of the VDR sequence in a number of different individuals. This was applied by Morrison et al. (1994) for the $3.2 \mathrm{~kb} 3^{\prime}$ untranslated region (UTR) of the gene when searching for additional polymorphisms and possible functional variations to explain an association of bone mineral density (BMD) differences with the (supposedly nonfunctional) BsmI RFLP. When they sequenced two subjects, who were homozygous for the most frequent BsmI-ApaI-TaqI haplotypes (see below), i.e., BAt-BAt and baT-baT, they reported 13 polymorphisms in $3.2 \mathrm{~kb}$, corresponding to the expected 1 in $300 \mathrm{bp}$ to be variant. Among the sequence differences they reported was a polyA-tract with a varying number of A-residues with alleles that vary in length between 12 and 18 adenosines. Durrin et al. (1999) expanded this approach and sequenced the $3^{\prime}$ UTR in five subjects homozygous for the baT-haplotype and three subjects homozygous for the BAt-haplotype and, in total, identified seven polymorphisms (see Fig. 3) of which four were common and three were rare in the eight subjects they analysed. Surprisingly, 


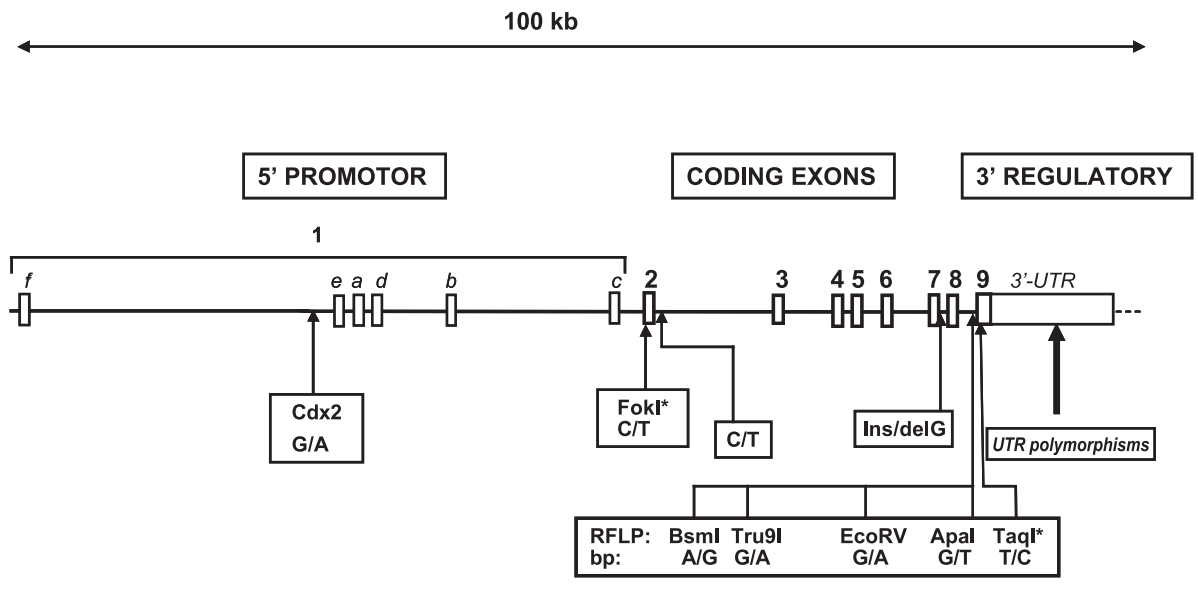

Fig. 2. Exon-intron structure of the VDR gene and position of known polymorphisms. * indicates that these polymorphisms are in the coding sequence. See text for further details on the polymorphisms. The $3^{\prime}$ UTR polymorphisms are shown in more detail in Fig. 5.

only two polymorphisms were found in both sequence analyses by Durrin et al. and Morrison et al. When considering the methods used and the number of subjects analysed, it seems likely that the polymorphisms reported by Durrin et al. do not contain sequence errors and seem to be more accurate. However, the number of subjects analysed is still limited and they were highly selected, so it is likely that more as yet uncovered polymorphisms exist in the $3.2 \mathrm{~kb}$ UTR (see below).

A similar sequence comparison approach was followed by Brown et al. (2000) when they analysed the coding region of the VDR gene in 59 parathyroid tumours to find mutations. Apart from the previously reported TaqI- and FokI-polymorphisms, they reported no polymorphisms in the coding region and found two intronic polymorphisms near exons 2 and 8 (shown in Fig. 2).
Another VDR polymorphism that was found through sequence analysis of a targeted area is the so-called $\mathrm{Cdx} 2$ polymorphism. Arai et al. (2001) reported a $G$ to A sequence variation among Japanese women in (what they thought was) the VDR 1a promoter when characterizing this promoter area of the VDR gene. The G to A polymorphism is in a binding site for an intestinal-specific transcription factor, called Cdx2 (Yamamoto et al., 1999). Recently, our laboratory has shown the $\mathrm{Cdx} 2$ polymorphism to be in the VDR 1e promoter (see Fig. 2), to be present among Caucasians as well as other race groups, and has developed an allele-specific genotyping assay for it (Fang et al., 2003).

Currently, it is possible to identify potential polymorphisms in silico through bio-informatic approaches by mining of databases such the NCBI SNP consortium
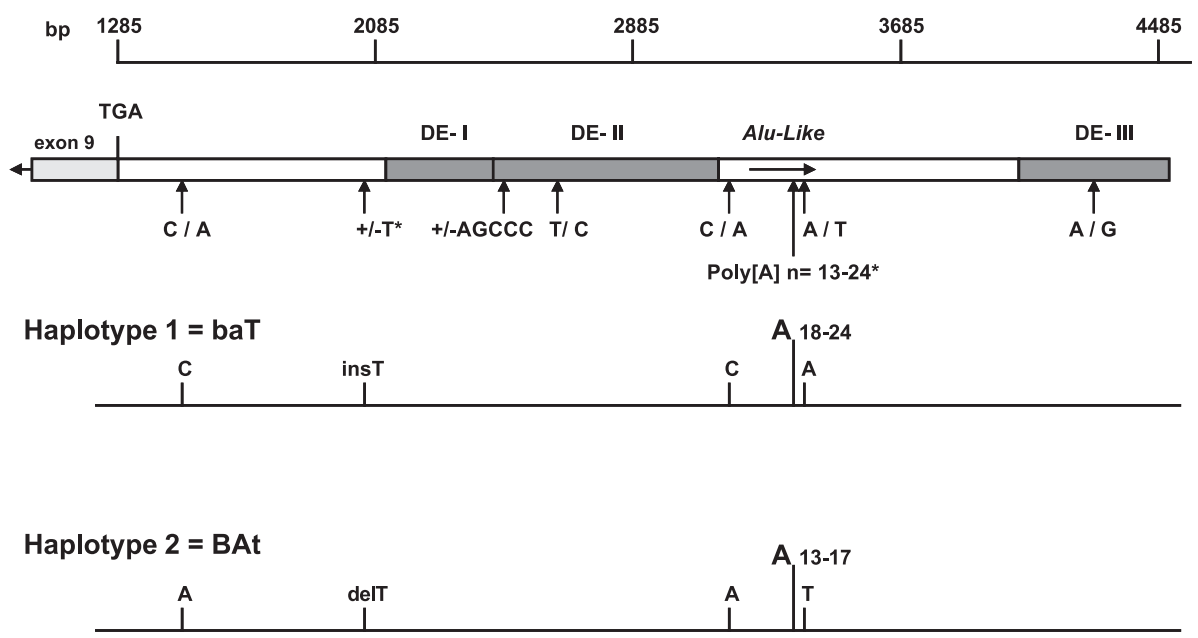

Fig. 3. Structure and position of polymorphisms in the $3^{\prime}$ UTR of the VDR gene based on Morrison et al. (1994) and Durrin et al. (1999). The bp numbering is according to Baker et al. (1988). TGA indicates the stop codon in exon 9 where the $3^{\prime}$ UTR starts. DE I-III refer to the so-called destabilising elements as identified by Durrin et al. Below, the two most frequent BsmI-ApaI-TaqI haplotypes across this part of the gene are depicted, i.e., haplotype 1 (=baT) and haplotype 2 (=BAt), and the alleles of the $3^{\prime}$ UTR polymorphisms to which they are linked based on eight subjects analysed. The $*$ indicates the polymorphisms which were identified in both studies. 
(http://www.ncbi.nlm.nih.gov/entrez/query.fcgi? $\mathrm{db}=\mathrm{snp}$ ) or the Celera database (http://www.celeradiscoverysystem. com). Indeed, many polymorphisms are usually reported in such databases for any gene of interest, but their validity has to be judged very carefully. For example, for the area which we analysed in detail for the VDR gene, only $40 \%$ of the polymorphisms currently reported in these databases turns out to be real (Fang and van Meurs, unpublished). Although we can expect the databases to improve over time, for polymorphism finding in the near future, it might therefore still be necessary to generate reliable sequence information from multiple individuals.

We have recently conducted such a more comprehensive study of the VDR gene and found 63 polymorphisms across $22 \mathrm{~kb}$ of sequenced parts the VDR gene (Fang et al., manuscript in preparation). Apart from the known polymorphisms shown in Figs. 2 and 3, a number of novel polymorphisms were found in the promoter areas including in and around exons $1 \mathrm{f}-1 \mathrm{c}$, in and around exons 2-9, and in the $3^{\prime}$ UTR. We found the majority of polymorphisms to be in regulatory areas rather than in coding exons. Since variation in the protein sequence could result in drastic functional effects, such as changes in affinity for the ligand or binding to DNA, it seems more likely that polymorphic variation and thus population variance would exist in areas of the gene that regulate the level of expression, such as the $5^{\prime}$ promoter area and the $3^{\prime}$ UTR region.

Once we know which polymorphisms are present in a certain candidate gene area, it is important to understand how they relate to each other, i.e., in a genetic sense as well as in a biologically functional sense. Genetically, we need to understand which alleles are linked to each other by studying the linkage disequilibrium between polymorphisms. Functionally, we have to determine how certain combinations of alleles across such a candidate gene might augment or diminish certain effects on gene function.

\section{Linkage disequilibrium and haplotypes}

Linkage disequilibrium (LD) measures describe the association (or co-occurrence) of alleles of adjacent polymorphisms with each other (Wall and Pritchard, 2003). This means, in practice, that one polymorphism can predict the other adjacent "linked" one because very little recombination has occurred between them over the time of evolution and population history. High levels of LD in a certain area will coincide with a limited number of "haplotypes" in that area. Haplotypes are blocks of linked alleles of adjacent polymorphisms whereby the length of such a block coincides with the strength of LD across the area. By analysis of polymorphisms across 51 autosomal areas in the human genome, it has become evident that, indeed, such haplotype blocks exist in the human genome (Gabriel et al.,
2002). The haplotype block size can vary between 5 to $>50$ $\mathrm{kb}$ with an average around $10-20 \mathrm{~kb}$. That means that frequent haplotype alleles can be found that encompass the polymorphic variation in such areas. In practice, this also means that relatively few polymorphisms have to be genotyped to "cover" the variance in a certain area. Therefore, a massive effort is currently going on to determine a haplotype map of the human genome (Gabriel et al., 2002; The International HapMap Consortium, 2003; Wall and Pritchard, 2003).

It follows that the LD and haplotype structure of a certain candidate gene is important for association analyses to understand how polymorphic variation in such a gene can contribute to risk of disease and population variance of certain phenotypes of interest. When a certain allele of a polymorphism has been found to be associated withsay-risk of fracture, it follows that this association might be explained by the effect of this particular allele, but also - because of LD and the haplotype structure - by one or more other alleles which happen to be linked to this allele within the haplotype. Once we know which haplotype carries this risk allele, we can determine by cell biological and molecular biological functional analyses which of the variants on that haplotype allele truly cause this effect.

Based on some of the known polymorphisms shown in Fig. 2, several studies have analysed the extent of linkage disequilibrium (LD) across the VDR gene. Since these analyses have used only a small number of polymorphisms, accurate information on LD and haplotypes so far has been very limited. Nevertheless, strong LD at the $3^{\prime}$ end of the gene has been observed early on for the BsmI-, ApaI-, EcoRV-, and TaqI-RFLPs (Morrison et al., 1992, 1994). This information was taken a step further by our laboratory to describe molecular haplotypes for these RFLPs (Uitterlinden et al., 1996). We identified five haplotype alleles in a large Caucasian population of which haplotypes 1 (baT; $48 \%$ ) and 2 (BAt; 40\%) were the most frequent and corresponded to the ones identified by Morrison et al. (1994). In line with this, strong LD was also observed between the BsmI RFLP and the polyA variable number of tandem repeat (VNTR) in the $3^{\prime}$ UTR (Ingles et al., 1997). This latter polymorphism has at least 12 different alleles (in 627 subjects analysed in Ingles et al., 1997 across five ethnic groups), but the allele size distribution of the polyA VNTR essentially follows a bimodal distribution. This pattern is such that this marker can be characterized as bi-allelic and that subjects can be classified as having alleles with short or long polyA stretches. Ingles et al. reported strong linkage between the " $b$ " allele and a long polyA stretch and the "B" allele and a short polyA stretch. Combined with the results of Morrison et al. (1994), Durrin et al. (1999), and our results (Uitterlinden et al., 1996), it follows that the Bsm-Apa-Taq haplotype 1 (baT) is linked to a large number of "A"s in the polyA VNTR $(n=18-24)$ while haplotype 2 (BAt) is linked to a smaller number of A's 
( $n=13-17)$ (see Fig. 3). Interestingly, several studies have shown that the FokI polymorphism showed no linkage to any of the other VDR polymorphisms.

Currently, it is important to assess linkage disequilibrium across other areas, e.g., 5' promoter, and to construct haplotype maps of the VDR. It is expected that these data will soon be available.

\section{Ethnic variation in polymorphisms}

VDR polymorphisms have been identified and analysed so far mostly in Caucasians and, to a lesser extent, in other ethnic groups. For example, the $\mathrm{Cdx} 2$ polymorphism was discovered in Japanese (Arai et al., 2001) and has only recently been analysed in Caucasians (Fang et al., 2003). For the most widely studied VDR polymorphisms, sometimes substantial differences have been noted between races and/or ethnic groups (see Table 1 and Zmuda et al., 2000). For example, the $\mathrm{f}$ or $\mathrm{T}$ allele of the FokI RFLP, corresponding with the 427 aa long VDR protein variant, occurs with lower frequency in Africans when compared to Caucasians and Asians, while the B allele of the BsmI RFLP has a lower frequency in Asians compared to Caucasians and Africans. Similarly, Ingles et al. (1997) showed differences between ethnic groups for the polyA VNTR in the $3^{\prime}$ UTR. We have found the frequency of the Cdx2 A allele to vary widely across different ethnic groups with the A allele being lowest in Caucasians, at about 19\% population frequency, and highest (74\%) in Africans (Fang et al., 2003).

Why do we see such differences? In general, all polymorphisms start as mutations which occur perhaps due to a DNA damage event, and then can grow in frequency in the

Table 1

Comparison of VDR allele frequencies across the three major ethnic groups for the most widely studied polymorphisms ${ }^{\mathrm{a}}$

\begin{tabular}{|c|c|c|c|c|}
\hline \multirow[t]{2}{*}{ VDR polymorphism } & \multirow[t]{2}{*}{ Minor alelle ${ }^{\mathrm{b}}$} & \multicolumn{3}{|c|}{ Ethnic group (\%) } \\
\hline & & Caucasian & Asian & African \\
\hline \multicolumn{5}{|c|}{ Individual polymorphisms } \\
\hline $\mathrm{Cd} 2$ & $\mathrm{~A}$ & 19 & 43 & 74 \\
\hline FokI & $\mathrm{f} \sim \mathrm{T}$ & 34 & 51 & 24 \\
\hline Bsm I & $\mathrm{B}$ & 42 & 7 & 36 \\
\hline ApaI & A & 44 & 74 & 31 \\
\hline $\operatorname{Taq} \mathrm{I}$ & $\mathrm{T}$ & 43 & 8 & 31 \\
\hline polyA & short $n=13-17$ & 41 & 12 & 29 \\
\hline \multicolumn{5}{|c|}{ Bsm-Apa-Taq haplotypes } \\
\hline & baT : haplotype 1 & 43 & 75 & 26 \\
\hline & BAt : haplotype 2 & 39 & 7 & 16 \\
\hline & bAT: haplotype 3 & 11 & 17 & 59 \\
\hline
\end{tabular}

${ }^{a}$ Data are from various sources (Arai et al., 1997; Durrin et al., 1999; Fang et al., 2003; Faraco et al., 1989; Gross et al., 1996; Ingles et al., 1997; Morrison et al., 1992; Morrison et al., 1994; Saijo et al., 1991; Sturzenbecker et al., 1994; Uitterlinden et al., 1996; Ye et al., 2000) and from Fang et al. (manuscript in preparation)

${ }^{\mathrm{b}}$ Minor allele in Caucasians; see text for details on definition of alleles. population and become true polymorphisms. Thus, allele frequency differences between ethnic groups most likely result from evolutionary processes and population genetic behaviour. The same holds true for the LD between the polymorphisms and the haplotype structure. Table 1 shows the frequencies of the Bsm-Apa-Taq haplotypes which we have recently determined in different ethnic groups (Fang et al., manuscript in preparation). They show complex patterns across ethnic groups which cannot be derived from the frequency differences of the individual composite polymorphisms. This is probably due to the existence of different sets of alleles linked together to form haplotypes across the $3^{\prime}$ end of the VDR gene. In other words, the haplotype " 1 " (or baT) in Caucasians is not defining the same set of linked alleles as the haplotype 1 in Asians or Africans. The set of haplotypes will reflect the out-of-Africa theory describing the origin of human populations across the globe and perhaps also will be due to gene-environment interactions in which certain variants might have had survival and/or reproductive advantages. One can assume that relatively "old" polymorphisms show little variation between different ethnic groups whereas relatively new polymorphisms might display large differences. In this respect, for example, the $\mathrm{Cdx} 2$ polymorphism appears relatively new and the FokI RFLP rather old.

For the interpretation of association studies, we can assume that individual functional polymorphisms might have the same functional effect in different ethnic groups because the physiological role of the vitamin $\mathrm{D}$ endocrine system will not be vastly different between ethnic groups. However, the individual polymorphisms will explain more or less the population variance given their difference in frequency between these ethnic groups. This is also the basis to for interpretation of ecological studies where allele frequencies across (ethnic) groups are correlated with the different incidence of disease/phenotype between such groups. For nonfunctional or anonymous polymorphisms, the situation is different because here, we rely on the LD that is detected by the polymorphism to explain its association with a disease. Moreover, as shown for the BsmApa-Taq haplotypes in Table 1, the frequencies of these "marker haplotypes" (consisting of nonfunctional polymorphisms which are markers for truly functional alleles elsewhere) are very different between ethnic groups. More importantly, as discussed above, the particular alleles that will be linked in the individual haplotypes are likely to be very different. Thus, if, for example, haplotype 1 is found associated in Caucasians and also in Africans, this can be due to linkage with a totally different functional allele. Alternatively, if an association of such a marker-haplotype is seen in Caucasians but, for example, not in Asians, this can be explained because the LD between the marker and the functional allele is different between these groups. This further emphasizes the absolute necessity to construct haplotype maps across the VDR as mentioned in the previous section. 
At this time, it is difficult to fully understand the consequences of ethnic allele variation, also because of the vastly different environmental factors between ethnic groups, such as diet and exercise. In addition, there are very different "genetic backgrounds" (i.e., the remainder of the genome and genetic variation therein) between ethnic groups in which these VDR polymorphisms interact with each other and with other genetic variants of other genes. It is therefore important to start by defining the haplotype structure of VDR polymorphisms in different ethnic groups. This will reveal which VDR alleles occur together on certain haplotypes and what their frequency is in different ethnic groups. Subsequently, together with the information on differences in environmental factors between ethnic groups, we can start to understand the relevant gene-environment interactions.

\section{Functionality of polymorphisms}

The interpretation of the association studies using VDR polymorphisms is severely hindered by the fact that most of the polymorphisms used are anonymous. The likely explanation for any observed association is then to assume the presence of a truly functional sequence variation elsewhere in the gene which is - to a certain extent-in linkage with an allele of the anonymous polymorphism used. As can be understood from the complex organization of the VDR gene (see Fig. 2), the identification of these functional polymorphisms in the VDR gene is a challenging enterprise. While these results are still eagerly awaited, several investigators have-nevertheless-over the past years, analysed multiple bioresponse parameters using the anonymous polymorphisms, including the BsmI RFLP, $B s m-A p a-T a q$ haplotypes, and the polyA VNTR in the $3^{\prime}$ UTR. These studies include in vitro cell biological and molecular biological studies, but also in vivo measurements of biochemical markers, and response to treatments with vitamin $\mathrm{D}$, calcium, and even hormone replacement therapy (HRT) or bisphosphonates. In Fig. 4, a schematic representation is shown of how functionality of polymorphisms can be tested at different levels, i.e., at the mRNA level, the protein level, the cell level, etc. In the optimal situation, the polymorphism is expected to show similar directions of the allelic effects at all these levels and thus allow to connect mechanisms at the molecular level with epidemiological findings at the population level. For the Cdx2 and the FokI polymorphism, this has now indeed been established to a large extent, while for the BsmIApaI-TaqI RFLPs and the polyA VNTR polymorphism, this is less certain and controversy still exists. Although one might argue that it is useless to perform any functional study with an anonymous polymorphism, results from such studies might still be informative because of the (strong) LD that is present between the marker polymorphisms and the truly functional polymorphism. An over-

\section{VDR DNA polymorphism}

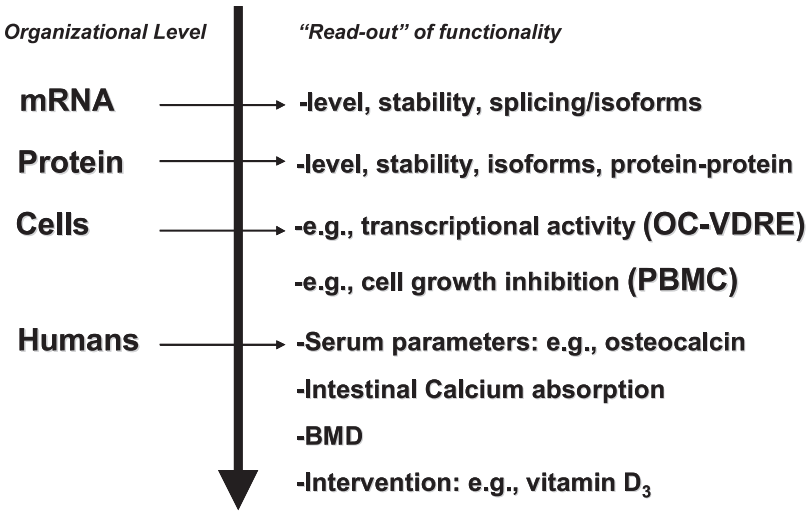

Association with disease

Fig. 4. Schematic depiction of the different organizational levels in physiology which determine the relation between a DNA polymorphism and the association with an endpoint in an epidemiological study, which are at the same time the levels at which functionality of VDR polymorphisms can be determined. Such functionality can be established using different types of readouts of test systems indicated on the right of the arrow. OC $\mathrm{VDRE}=$ osteocalcin vitamin $\mathrm{D}$ responsive element. $\mathrm{PBMC}=$ peripheral blood mononuclear cell.

view of the functional studies for each of these VDR polymorphisms is presented in Tables $2 \mathrm{~A}-\mathrm{C}$ and these are discussed below.

\subsection{Cdx2 polymorphism}

The Cdx2 polymorphism has been well characterized by the studies of Arai et al. (2001) and Yamamoto et al. (1999). The $\mathrm{G}$ to A polymorphism is located in a Cdx2 binding site in the 1e promoter region, and this site is suggested to play an important role in intestinal-specific transcription of the VDR gene. As the intestine is the predominant area for calcium absorption, the $\mathrm{Cdx} 2$ site is thought to influence the vitamin D regulation of calcium absorption. The A allele has been demonstrated to be more "active" than the G-allele by binding the $\mathrm{Cdx} 2$ transcription factor more strongly and by having more transcriptional activity (Arai et al., 2001). Thus, the A allele is thought to cause increased VDR expression in the intestine and, thereby, can increase the transcription of calcium transport proteins (such as calbindin $9 \mathrm{~K}$ and $-28 \mathrm{~K}$, TRPV5, TRPV6). This could thereby enhance the intestinal absorption of calcium and, thereby, to result in increased BMD. Although this increased BMD has indeed been demonstrated for Japanese women who carry the A allele (Arai et al., 2001), this was not found in Caucasian women (Fang et al., 2003). Yet, the A allele of this polymorphism was indeed found to be associated with decreased fracture risk (as would be expected from having an increased BMD) in a large study of Caucasian women, but independently of BMD (Fang et al., 2003). Although the functionality of this polymorphism has indeed been 
Table 2A

Functional effects of VDR polymorphisms: in vitro studies

\begin{tabular}{|c|c|c|c|c|c|c|c|}
\hline \multirow[t]{2}{*}{ Polymorphism } & \multirow[t]{2}{*}{ Refs. } & \multirow[t]{2}{*}{ Cell type } & \multicolumn{4}{|c|}{ Allelic differences } & \multirow[t]{2}{*}{ Mechanism } \\
\hline & & & $\begin{array}{l}\text { VDR } \\
\text { expression }\end{array}$ & $\begin{array}{l}\text { VDR mRNA } \\
\text { stability }\end{array}$ & $\begin{array}{l}\text { Transactivation } \\
\text { by VDR }\end{array}$ & $\begin{array}{l}\text { Cell growth } \\
\text { inhibition }\end{array}$ & \\
\hline $\mathrm{Cdx} 2 ; \mathrm{A}$ to $\mathrm{G}$ & $\begin{array}{l}\text { (Yamamoto } \\
\text { et al., 1999) }\end{array}$ & Caco-2 intestinal cell line & $\mathrm{A}>\mathrm{G}$ & - & $\mathrm{A}>\mathrm{G}$ & & $\begin{array}{l}\text { The } \mathrm{G} \text { allele } \\
\text { diminished } \mathrm{Cd} \times 2 \\
\text { transcription factor } \\
\text { binding }\end{array}$ \\
\hline \multirow{7}{*}{$\begin{array}{l}\text { FokI; C (F; } 424 \\
\text { aa; M4) to T } \\
\text { (f; } 427 \text { aa; M1) }\end{array}$} & (Arai et al., 1997) & Hela cell line & - & - & 424 aа $>427$ aа & - & \\
\hline & (Gross et al., 1998a) & GMK-Cos7 & ND & - & ND & - & \\
\hline & & Human fibroblasts & ND & - & ND & - & \\
\hline & (Correa et al., 1999) & Parathyroid adenomas & ND & - & - & - & \\
\hline & (Jurutka et al., 2000) & COS7, Hela, ROS 2/3 & ND & - & 424 aа $>427$ aa & - & $\begin{array}{l}\text { The } 424 \text { aa VDR (M4) } \\
\text { interacts more efficiently } \\
\text { with transcription factor } \\
\text { TFIIB }\end{array}$ \\
\hline & (Whitfield et al., 2001) & $\begin{array}{l}\text { Human } \\
\text { fibroblasts }(n=20)\end{array}$ & - & - & 424 aа $>427$ aа & - & \\
\hline & (Colin et al., 2000) & Human PBMC $(n=72)$ & - & - & - & $\begin{array}{l}424 \\
\text { aa>427 aa }\end{array}$ & \\
\hline \multirow[t]{14}{*}{$\begin{array}{l}\text { Bsm, Apa, Taq, } \\
\text { UTR (polyA } \\
\text { VNTR) }\end{array}$} & (Morrison et al., 1994) & GMK Cos-7 & $\mathrm{BAt}>\mathrm{baT}$ & - & - & - & $\begin{array}{l}\text { mRNA stability } \\
\text { of BAt is larger } \\
\text { than that of baT? }\end{array}$ \\
\hline & & ROS $17 / 2.8$ & BAt $>$ baT & - & - & - & \\
\hline & (Whitfield et al., 2001) & GMK Cos-7 & ND & ND & - & - & \\
\hline & & Human osteoblast & $\mathrm{baT}>\mathrm{BAt}$ & $\mathrm{baT}>\mathrm{BAt}$ & - & - & \\
\hline & (Durrin et al., 1999) & Mouse NIH3T3 cells & ND & ND & - & - & \\
\hline & (Crofts et al., 1996) & $\begin{array}{l}\text { Human fibroplast }(n=9) \\
\text { PBL }(n=13)\end{array}$ & $(\mathrm{ba}) \mathrm{T}>(\mathrm{BA}) \mathrm{t}$ & - & - & - & \\
\hline & (Gross et al., 1998b) & $\begin{array}{l}\text { Human } \\
\text { fibroblasts }(n=9)\end{array}$ & ND & - & ND & - & \\
\hline & (Whitfield et al., 2001) & $\begin{array}{l}\text { Human fibroblasts } \\
(n=11)\end{array}$ & - & - & $\mathrm{L}>\mathrm{S}(\mathrm{baT}>\mathrm{BAt})$ & - & \\
\hline & (Yamagata et al., 1999) & $\begin{array}{l}\text { Human PBMC } \\
(n=24 ; \text { Japanese })\end{array}$ & $(\mathrm{BA}) \mathrm{t}>(\mathrm{ba}) \mathrm{T}$ & - & - & - & \\
\hline & (Mocharla et al., 1997) & Human PBMC $(n=38)$ & ND & - & - & - & \\
\hline & (Colin et al., 2000) & Human PBMC $(n=72)$ & - & - & - & ND & \\
\hline & (Verbeek et al., 1997) & $\begin{array}{l}\text { Human PBL, leukemia } \\
\text { cell line, prostate } \\
\text { cell line }\end{array}$ & (ba) $\mathrm{T}>(\mathrm{BA}) \mathrm{t}$ & ND & - & - & \\
\hline & $\begin{array}{l}\text { (Carling et al., } \\
\text { 1997, 1998) }\end{array}$ & $\begin{array}{l}\text { Human parathyroid } \\
\text { adenomas }(n=42)\end{array}$ & $\mathrm{BAt}>\mathrm{baT}$ & - & - & BAt $>$ baT & \\
\hline & (Ohtera et al., 2001) & $\begin{array}{l}\text { Human osteoblasts } \\
(n=18 ; \text { Japanese })\end{array}$ & - & - & baT $>$ BAt & - & \\
\hline
\end{tabular}

$\mathrm{GMK}=$ green monkey kidney; $\mathrm{PBMC}=$ peripheral blood mononuclear cells; $\mathrm{PBL}=$ peripheral blood lymphocytes; $-=$ not analysed; ND= no difference

convincingly demonstrated, the exact mechanism whereby the A allele would confer lower risk for fracture has not been elucidated yet and requires further study.

\subsection{FokI polymorphism}

From the genetic perspective, it is important to note that the FokI RFLP can be considered an independent marker in the VDR gene since there is no LD with any of the other VDR polymorphisms and the LD area surrounding this polymorphism seems to be very small (Fang et al., manuscript in preparation). Therefore, LD with another polymorphism is not a likely explanation for the associations observed with this polymorphism, and so functional studies should be focussed on the polymorphism itself. In a study by Arai et al. (1997), evidence for the functionality of the FokI polymorphism was obtained. Results from transcriptional activation studies in transfected HeLa cells using a reporter construct under the control of a short portion of the rat 24-hydroxylase gene promoter region $(-291-+9)$ containing a vitamin D responsive element (VDRE) suggested the short 424 amino acid VDR protein variant (corresponding with the $\mathrm{C}$-allele or "big F" allele) to be more active than the long 427 aa variant, with a 1.7 -fold difference between the two variants. Gross et al. (1998a) were not able to confirm these results. They also analysed 
FokI allelic differences in the transcription activation characteristics of the VDR protein, but now in COS7 cells and using the rat 24-hydroxylase promoter, although containing a slightly larger region of the promoter $(-1399-+76)$. In addition, they analysed VDREs from the human osteocalcin gene and the rat osteopontin gene but could not see FokI allelic differences in these systems. Yet, the authors noted that it might be difficult to observe the relatively small effects of this polymorphism in these test systems. Moreover, small differences in cell type, promoter area, and gene specificity of the VDRE might be crucial to see an allelic difference. Jurutka et al. (2000) demonstrated the 424 aa VDR variant to interact more efficiently with the transcription factor TFIIB, using reporter constructs containing 1100 bp of a rat osteocalcin promoter in COS7-, HeLa, and ROS2/ 3 cells. The authors concluded the 424 aa short VDR variant to represent a more transcriptionally potent VDR protein. This notion was corroborated by the same authors in the analysis of 20 fibroblast cell lines of different endogenous FokI VDR genotype using a reporter construct containing four copies of the rat osteocalcin gene (Jurutka et al., 2000). Results from our own laboratory (Colin et al., 2000) seem to confirm the higher activity of the 424 aa short VDR variant while using a different readout of functionality. We tested capacity for growth inhibition by vitamin $\mathrm{D}$ in peripheral blood mononuclear cells (PBMCs) of different genotype for the FokI RFLP in cells derived from 72 postmenopausal women (Colin et al., 2000). We observed that the PBMCs carrying the "F" allele (corresponding to the 424 aa short variant) had a lower ED50 and thus had a more active VDR variant in inhibiting the (PHA-induced) cell growth.

In conclusion, we can state that the FokI polymorphism seems to be functional and that the 424 aa VDR variant is somewhat more active than the 427 aa variant in terms of its transactivation capacity as a transcription factor. There might be a gene-specific effect in that some promoter areas of vitamin D target genes might be more sensitive to this VDR genotype-dependent difference in activity, while others may not. Together with cell-type-specific interaction with co-transcription factors, this might result in a cell-typespecific and organ-specific expression of the genotypedependent differences.

\subsection{Bsm-Apa-Taq and 3' UTR polymorphisms}

Most efforts to identify functional sequence variations in the VDR gene have been focussed on the $3^{\prime}$ regulatory region because this is close to the anonymous markers used mostly so far in association studies (see Figs. 2 and 3). While the BsmI, ApaI, and TaqI RFLPs are located near the $3^{\prime}$ end of the gene, the LD extends into the $3^{\prime}$ regulatory region containing the UTR. We already saw that the $3^{\prime}$ UTR of the VDR gene contains many polymorphisms and thus, through the strong LD, these might explain associations observed with Bsm-Apa and/or Taq RFLPs. The 3' UTR of genes is known to be involved in regulation of expression, especially through regulation of mRNA stability, including for steroid receptors which contain extensive $3^{\prime}$ UTRs, such as the glucocorticoid receptor alpha (Decker and Parker, 1995). For the latter, receptor polymorphisms in the $3^{\prime}$ UTR have been described in the so-called AUUUA-motifs which influence the mRNA stability (Schaaf and Cidlowski, 2002).

Morrison et al. provided evidence of differential luciferase activity for the two $3^{\prime}$ UTR-variants that are linked to the two most frequent haplotypes, i.e., "baT" (haplotype 1 according to Uitterlinden et al., 1996) and "BAt" (haplotype 2). Durrin et al. (1999) have shown certain parts of the UTR, so-called destabilizing elements, to be involved in determining stability of the VDR-mRNA. However, they did not find the UTRs linked to either "baT" or "BAt" haplotype to differ with respect to mRNA stability (Durrin et al. 1999). They used heterologous constructs (human VDRUTR sequences coupled to a rabbit $\beta$-globin gene) and cell types (mouse NIH3T3 cells) to test for functionality. Especially, since it is known that $3^{\prime}$ UTRs display cell-typespecific effects on mRNA stability, this could be important in demonstrating functionality of sequence variations in the UTR. Although it is assumed that mRNA stability differences might underlie the allelic differences, alternative explanations should still be considered. Other studies have analysed differences in expression levels according to the $3^{\prime}$ polymorphisms, and although there is a tendency for the BAt haplotype to display overall somewhat higher levels of mRNA expression than baT, the results have not been consistent (see Table 2A).

Recently, Whitfield et al. (2001) demonstrated functional significance of the translation initiation codon polymorphism (detected as FokI RFLP) and the poly(A) stretch in the 3' UTR. In a series of 20 fibroblast cell lines of different VDR genotype, the relative transcription efficiency of the endogenous VDR protein which was differing by the genotype at both the FokI RFLP (F and f alleles) and the poly(A) stretch with long (L) and short (S) alleles was measured. The endogenous VDR protein is then acting as a transcription factor for a 1,25-dihydroxyvitamin $\mathrm{D}_{3}$-responsive reporter gene (containing the rat osteocalcin gene VDRE) which is transfected in the cell. This study provided evidence for so-called high (of the "FL" genotype) and low (of the "fS" genotype) VDR activity. One of the possible explanations mentioned included differences in translational activity (rather than mRNA stability) of the different mRNA-3' UTR variants. However, further research is necessary to prove that assumption. In any case, this study also illustrated the importance of analysing multiple polymorphisms in the VDR gene in relation to each other (as is illustrated in Fig. 5; see below).

At another level, the responses by VDR genotype have been analysed as differences in serum markers (Table 2B). VDR is then thought to act on vitamin D responsive genes, e.g., through gene-specific VDREs, which results in certain protein/protein fragments being excreted into the circulation. These 17 studies include several different serum 


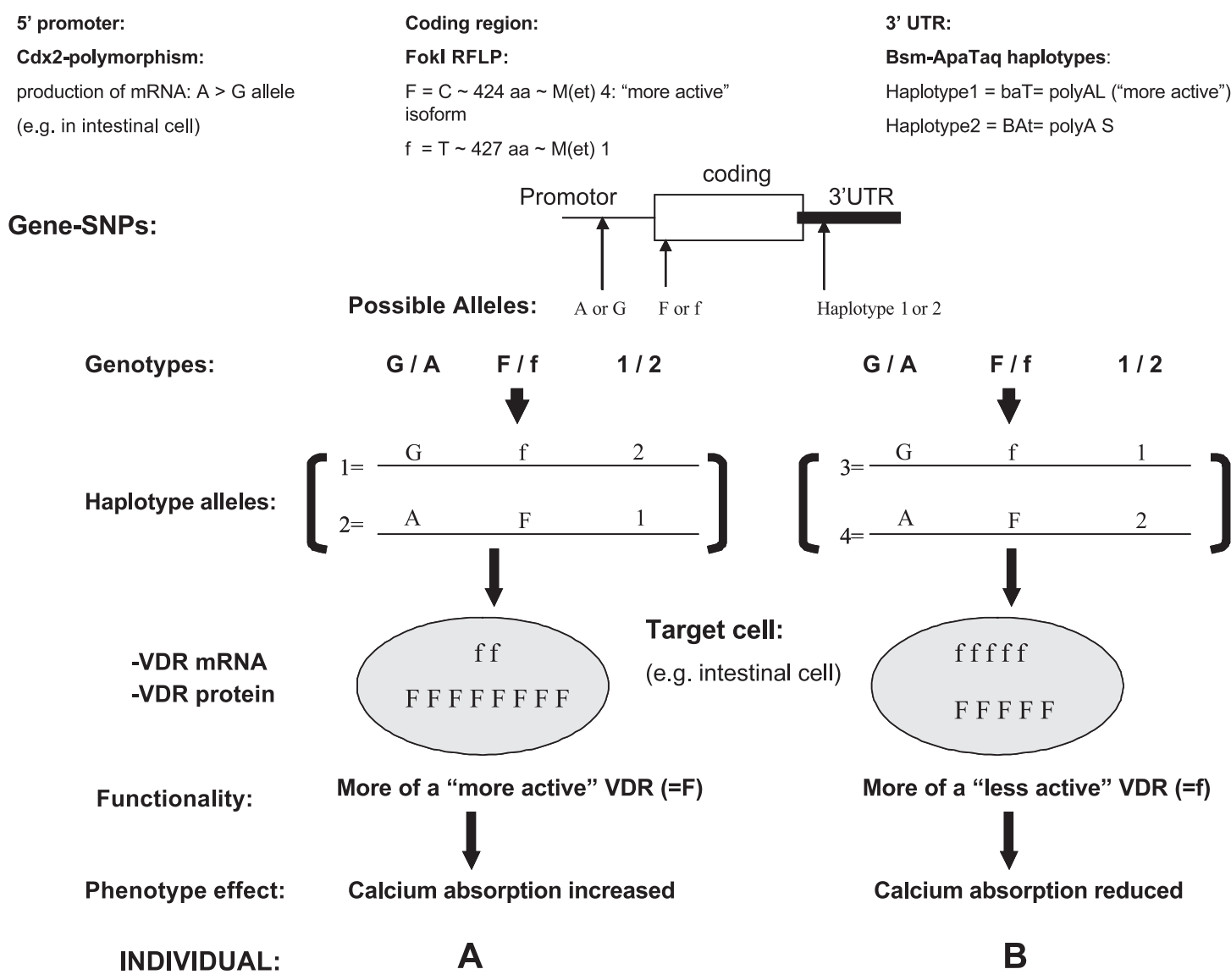

Fig. 5. The importance of gene-wide haplotypes in the VDR gene. Three adjacent SNPs in different parts of the VDR gene are shown for two individuals (A and B indicated at the bottom). The subjects A and B have identical genotypes, i.e., they are both heterozygous for all three SNPs. However, they have different haplotype combinations: $1+2$ for subject $A$ and $3+4$ for subject $B$. The promoter area regulates production of mRNA, while the $3^{\prime}$ UTR is involved in stability/degradation of mRNA, and their interaction/combined effects regulates the net availability of the mRNA for translation into the VDR protein. In this case, the example is shown for the $\mathrm{Cdx} 2$ promoter polymorphism which has two alleles $\mathrm{A}$ and $\mathrm{G}$, of which the A allele is the more active variant in intestinal cells. For the $3^{\prime}$ UTR, the two different variants, haplotype 1 and haplotype 2, are presented consisting of haplotypes of the Bsm-Apa-Taq RFLPs. The haplotype 1 is supposedly the more active/less unstable $3^{\prime}$ UTR resulting in more VDR protein being produced. The VDR protein can occur in two variants: "little f" (less active, M1, 427 aa) and "big F" (more active, M4, 423 aa), and both A and B are heterozygous for this polymorphism. The result of the particular haplotype combinations is that individual A has less of the "risk" VDR protein, i.e., the little $\mathrm{f}$ variant, M1, 427 aa long, than individual B in the target cell. This could not have been predicted by analysing single SNPs and/or only looking at genotypes of individual SNPs, but is only evident upon analysis of the gene-wide haplotypes.

markers thought to be vitamin-D-specific, such as osteocalcin and PTH. In particular, osteocalcin has been analysed because this is a highly vitamin-D-responsive gene and it is frequently measured in clinical practice to monitor bone metabolism (for bone formation activity). Although 7 (out of 17) studies were not able to detect genotype-dependent differences in serum levels of osteocalcin (or other bone markers), 8 studies reported individuals with the BAt haplotype to have higher osteocalcin levels than those with the baT haplotype, while 3 (out of 17) studies observed an opposite trend.

A similar pattern can be distinguished when we analyse the studies which determined the in vivo response to treatment by VDR genotype (Table 2C). Studies included the analysis of response to treatment with calcitriol, calcium, corticosteroids, HRT, and etidronate and responses mostly involved measuring changes in
BMD. Four out of nine studies reported the response for BAt to be better than for baT. However, three out of nine showed the opposite effect while three showed no effect. Complicating factors to interpret these studies are of course the different endpoints being measured and the different polymorphisms in usually (and understandably) small studies most likely lacking power to demonstrate subtle effects.

Thus, when we overlook Tables $2 \mathrm{~A}-\mathrm{C}$, the picture is still complicated, but there seems to be a trend for the BAthaplotype (linked to short polyA VNTR alleles in the $3^{\prime}$ UTR) to display somewhat better responses than the baT-haplotype (linked to long polyA VNTR alleles). Together with the in vitro studies, there is therefore some argument to state that it might indeed be haplotype 2 (BAt) which - in general - confers a better response than haplotype 1 (baT). It is tempting to speculate that perhaps this is 
Table 2B

Functional effects of VDR polymorphisms: in vivo studies ${ }^{\mathrm{a}}$

\begin{tabular}{|c|c|c|c|}
\hline Polymorphism & Refs. & Marker & Allelic effect: serum concentration \\
\hline Bsm, Apa, EcoRV & (Morrison et al., 1992) & Osteocalcin $(n=91)$ & $\mathrm{BA}(\mathrm{t})>\mathrm{ba}(\mathrm{T})$ \\
\hline Bsm & (Morrison et al., 1994) & Calcitriol $(n=117)$ & $\mathrm{B}(\mathrm{At})>\mathrm{b}(\mathrm{aT})$ \\
\hline Bsm & (Kroger et al., 1995) & Osteocalcin, ICTP $(n=23)$ & $\mathrm{b}(\mathrm{aT})>\mathrm{B}(\mathrm{At})$ \\
\hline Bsm & (Fleet et al., 1995) & Osteocalcin, calcitriol $(n=154)$ & ND \\
\hline Bsm Apa Taq & (Garnero et al., 1995) & Osteocalcin, $25(\mathrm{OH})$, etc. $(n=189)$ & $\mathrm{B}(\mathrm{At})>\mathrm{b}(\mathrm{aT}): \mathrm{NS}$ trend $^{\mathrm{b}}$ \\
\hline Bsm & (Krall et al., 1995) & $1,25(\mathrm{OH}) 2 \mathrm{D}(n=229)$ & ND \\
\hline Bsm & (Howard et al., 1995) & Osteocalcin, calcitriol, ICTP $(n=21)$ & $\mathrm{B}(\mathrm{At})>\mathrm{b}(\mathrm{aT})$ \\
\hline Bsm Apa Taq & (Tokita et al., 1996) & $\begin{array}{l}\text { Osteocalcin, BAP, } 1,25(\mathrm{OH}) 2 \mathrm{D} \\
(n=159 ; \text { Japanese })\end{array}$ & $\mathrm{BAt}>\mathrm{baT}$ \\
\hline Bsm Apa Taq & (Tsai et al., 1996) & $\begin{array}{l}\text { Osteocalcin, BAP, PICP, NTX } \\
(n=268 ; \text { Chinese })\end{array}$ & ND \\
\hline Bsm & (Mocharla et al., 1997) & Osteocalcin, calcitriol $(n=38)$ & ND \\
\hline Bsm & (Rauch et al., 1997) & Osteocalcin, AlkPhosp, PICP $(n=50)$ & $\mathrm{B}(\mathrm{At})>\mathrm{b}(\mathrm{aT}): \mathrm{NS}$ trend \\
\hline Bsm Apa Taq & (McClure et al., 1997) & Osteocalcin, calcitriol, PTH $(n=103)$ & $\begin{array}{l}\text { BAt }>\text { baT: NS trend for PTH, calcitriol } \\
\text { baT }>\text { BAt: NS trend for osteocalcin }\end{array}$ \\
\hline Bsm & (Graafmans et al., 1997) & Osteocalcin, calcitriol & $\mathrm{ND}$ \\
\hline Bsm & (Hansen et al., 1998) & Osteocalcin, 25(OH), BAP $(n=200)$ & ND \\
\hline Bsm, FokI & $\begin{array}{l}\text { (Sowers et al., 1999; } \\
\text { Willing et al., 1998) }\end{array}$ & $\begin{array}{l}\text { Osteocalcin, PTH, } 25(\mathrm{OH}) \\
(n=372 ; n=261)\end{array}$ & ND \\
\hline Bsm & (Ferrari et al., 1999) & $\begin{array}{l}\text { Osteocalcin, } \mathrm{PTH} \\
(n=72 \text { young men })\end{array}$ & $\mathrm{B}(\mathrm{At})>\mathrm{b}(\mathrm{aT})$ \\
\hline Bsm Apa Taq & (Bell et al., 2001) & $\begin{array}{l}\text { Osteocalcin, PTH, } 1,25 \\
(\mathrm{OH}) 2 \mathrm{D}(n=39 \text { African } \\
\text { men, } n=44 \text { Caucasian men) }\end{array}$ & (b)a(T) $>(\mathrm{B}) \mathrm{A}(\mathrm{t})$ for PICP \\
\hline
\end{tabular}

${ }^{a}$ Studies used either one or all of the $3^{\prime}$ polymorphisms, i.e., BsmI, ApaI, EcoRV, and TaqI. To relate these results to what is described in this chapter for sequence variation at the $3^{\prime}$ end of the VDR gene, the genotypes and allelic effects are presented as haplotypes 1 (baT) or 2 (BAt). Letters in brackets refer to polymorphisms not actually tested in the study but inferred by this author based on VDR haplotype structure in the $3^{\prime}$ area. All studies are in Caucasians unless stated otherwise.

${ }^{\mathrm{b}} \mathrm{NS}$ trend: nonsignificant trend; $\mathrm{ND}=$ no difference.

due to a slightly better mRNA stability and half-life. This would theoretically result in higher numbers of VDR being present in the target cell and thus giving this target cell a better response to vitamin $\mathrm{D}$.

In view of what has been discussed above, it is not very surprising that these "functional" studies have shown alleles of only few polymorphisms being consistently associated with all of the different parameters of functionality such as displayed in Fig. 4. This holds true for the FokI polymorphism and the Cdx2 polymorphism. Yet, the studies of the $3^{\prime}$ polymorphisms have been hampered. Major caveats of these studies are (a) the use of the anonymous rather than functional polymorphisms to group subjects and cells by genotype and (b) the use of different types of bioresponses and different cell types and cell culture conditions in which the vitamin $\mathrm{D}$ response might not be evident under the conditions of the experiment. Therefore, the identification of truly functional polymorphisms in the $3^{\prime}$ UTR and the use of different well-defined cell types will help in clarifying the molecular mechanisms underlying the associations observed especially for the $3^{\prime}$ polymorphisms such as Bsm I, ApaI, and TaqI.

Table $2 \mathrm{C}$

Functional effects of VDR polymorphisms: in vivo studies of response to treatment

\begin{tabular}{|c|c|c|c|c|}
\hline \multirow[t]{2}{*}{ Polymorphism } & \multirow[t]{2}{*}{ Refs. } & \multirow[t]{2}{*}{ Treatment } & \multicolumn{2}{|l|}{ Response } \\
\hline & & & Serum markers & BMD \\
\hline Bsm & (Howard et al., 1995) & 7 days calcitriol $(n=21)$ & $\mathrm{b}(\mathrm{aT})>\mathrm{B}(\mathrm{At})$ & - \\
\hline Bsm Apa Taq & (Matsuyama et al., 1995) & 12 months 1alphaOH-D3 $(n=115)$ & - & $\mathrm{baT}>\mathrm{BAt}$ \\
\hline Bsm & (Graafmans et al., 1997) & 2 years calcitriol $(n=81)$ & ND & $\mathrm{B}(\mathrm{At})>\mathrm{b}(\mathrm{aT})$ \\
\hline Bsm & (Krall et al., 1995) & 2 years calcium $(n=229)$ & - & $\mathrm{B}(\mathrm{At})>\mathrm{b}(\mathrm{aT})$ \\
\hline Bsm & (Deng et al., 1998) & 3.5 years HRT $(n=108)$ & - & $\mathrm{B}(\mathrm{aT})>\mathrm{B}(\mathrm{At})$ \\
\hline Apa Taq & (Kurabayashi et al., 1999) & 1 year HRT $(n=82)$ & - & (ba) $\mathrm{T}>(\mathrm{BA}) \mathrm{t}$ \\
\hline Bsm Taq & (Ho et al., 1999) & $>1$ year corticosteroids $(n=263)$ & - & ND \\
\hline Bsm & (Marc et al., 1999) & 1 year etidronate $(n=24)$ & - & $\mathrm{B}(\mathrm{At})>\mathrm{b}(\mathrm{aT})$ \\
\hline FokI & (Kurabayashi et al., 1999) & 1 year HRT $(n=82)$ & - & ND \\
\hline
\end{tabular}

$\mathrm{ND}=$ no difference. 
In addition, it is very important to analyse all known VDR polymorphisms and their interrelationships in such experiments since they will interact with each other to determine VDR expression and activity (see Fig. 5). This was already indicated by the work of Whitfield et al. (2001) and this is further illustrated in Fig. 5 where the interaction of promoter-, coding-, and 3' UTR-polymorphisms is highlighted. In a normally active cell, certain promoter polymorphisms will "join forces" with certain 3' UTR polymorphisms in regulating the amount of VDR mRNA being available in a certain target cell. Together, they determine the expression of the known FokI variants, F and $f$, which are the (functionally different) VDR proteins that act, for example, on VDREs to activate certain vitamin $\mathrm{D}$ responsive genes to be expressed. In the example, subjects $\mathrm{A}$ and $\mathrm{B}$ have identical genotypes at three polymorphisms (the Cdx2, the FokI, and the Bsm-Apa-Taq 3' UTR polymorphisms) but only differ in their particular combinations of alleles on chromosomes (i.e., their haplotypes). This ultimately results in less "high-activity" VDR proteins (i.e., having the "F" allele) being expressed in cells of subject B, which is then expected to display lower responses to vitamin D. In this case, the $\mathrm{Cdx} 2$ promoter variant is involved and differences between subjects are then expected at the level of calcium absorption in intestinal cells. However, when only one of the polymorphisms would have been tested in cell biological experiments, this would not have been detected (unless very large genotype groups would have been analysed to detect the individual subtle differences). Moreover, when only the three individual polymorphisms would have been analysed and the haplotypes would not have been taken into account, these effects would also not have been noticed. Thus, not controlling for the underlying complexities in VDR polymorphisms, i.e., by not analysing multiple polymorphisms and analysing their haplotypes, can also help to explain contradictory results from in vitro and in vivo functional experiments.

\section{Conclusion}

Since the first publications on polymorphisms in the VDR in 1992, considerable progress has been made in unraveling the VDR in genetic terms as exemplified by the elucidation of the genomic localization, structure, and polymorphisms. A next important phase that is currently in progress and which is strongly facilitated by the data from the Human Genome Project is the establishment of LD and construction of haplotype maps. A most challenging and demanding area is the assessment of consequences of polymorphisms for the VDR function. First small steps have been made to address this issue, but an important progress is needed, which may find its basis in a synergy between the ongoing genetic analysis of the VDR and the increasing knowledge on molecular mechanisms and cellular specificity of vitamin D action.
Knowledge of the molecular and functional consequences of the VDR polymorphisms is crucial to fully appreciate their significance and understand their potential clinical implications.

\section{References}

Arai, H., Miyamoto, K., Taketani, Y., Yamamoto, H., Iemori, Y., Morita, K., Tonai, T., Nishisho, T., Mori, S., Takeda, E., 1997. A vitamin D receptor gene polymorphism in the translation initiation codon: effect on protein activity and relation to bone mineral density in Japanese women. J. Bone Miner. Res. 12, 915-921.

Arai, H., Miyamoto, K.I., Yoshida, M., Yamamoto, H., Taketani, Y., Morita, K., Kubota, M., Yoshida, S., Ikeda, M., Watabe, F., Kanemasa, Y., Takeda, E., 2001. The polymorphism in the caudal-related homeodomain protein $\mathrm{Cdx}-2$ binding element in the human vitamin D receptor gene. J. Bone Miner. Res. 16, 1256-1264.

Baker, A.R., McDonnell, D.P., Hughes, M., Crisp, T.M., Mangelsdorf, D.J., Haussler, M.R., Pike, J.W., Shine, J., O’Malley, B.W., 1988. Cloning and expression of full-length cDNA encoding human vitamin D receptor. Proc. Natl. Acad. Sci. U. S. A. 85, 3294-3298.

Bell, N.H., Morrison, N.A., Nguyen, T.V., Eisman, J., Hollis, B.W., 2001. ApaI polymorphisms of the vitamin D receptor predict bone density of the lumbar spine and not racial difference in bone density in young men. J. Lab. Clin. Med. 137, 133-140.

Brown, S.B., Brierley, T.T., Palanisamy, N., Salusky, I.B., Goodman, W., Brandi, M.L., Drueke, T.B., Sarfati, E., Urena, P., Chaganti, R.S., Pike, J.W., Arnold, A., 2000. Vitamin D receptor as a candidate tumor-suppressor gene in severe hyperparathyroidism of uremia. J. Clin. Endocrinol. Metab. 85, 868-872.

Carling, T., Ridefelt, P., Hellman, P., Rastad, J., Akerstrom, G., 1997. Vitamin D receptor polymorphisms correlate to parathyroid cell function in primary hyperparathyroidism. J. Clin. Endocrinol. Metab. 82, $1772-1775$.

Carling, T., Rastad, J., Akerstrom, G., Westin, G., 1998. Vitamin D receptor (VDR) and parathyroid hormone messenger ribonucleic acid levels correspond to polymorphic VDR alleles in human parathyroid tumors. J. Clin. Endocrinol. Metab. 83, 2255-2259.

Colin, E.M., Weel, A.E., Uitterlinden, A.G., Buurman, C.J., Birkenhager, J.C., Pols, H.A., van Leeuwen, J.P., 2000. Consequences of vitamin D receptor gene polymorphisms for growth inhibition of cultured human peripheral blood mononuclear cells by 1, 25-dihydroxyvitamin D3 . Clin. Endocrinol. (Oxf.) 52, 211-216.

Correa, P., Rastad, J., Schwarz, P., Westin, G., Kindmark, A., Lundgren, E., Akerstrom, G., Carling, T., 1999. The vitamin D receptor (VDR) start codon polymorphism in primary hyperparathyroidism and parathyroid VDR messenger ribonucleic acid levels. J. Clin. Endocrinol. Metab. 84, 1690-1694.

Crofts, L., Morrison, N., Eisman, J., 1996. Differential expression of VDR gene alleles. J. Bone Miner. Res. 11, S208 (Abstract).

Crofts, L.A., Hancock, M.S., Morrison, N.A., Eisman, J.A., 1998. Multiple promoters direct the tissue-specific expression of novel N-terminal variant human vitamin D receptor gene transcripts. Proc. Natl. Acad. Sci. USA 95, 10529-10534.

Decker, C.J., Parker, R., 1995. Diversity of cytoplasmic functions for the $3^{\prime}$ untranslated region of eukaryotic transcripts. Curr. Opin. Cell Biol. 7, 386-392.

Deng, H.W., Li, J., Li, J.L., Johnson, M., Gong, G., Davis, K.M., Recker, R.R., 1998. Change of bone mass in postmenopausal Caucasian women with and without hormone replacement therapy is associated with vitamin D receptor and estrogen receptor genotypes. Hum. Genet. 103, 576-585.

Durrin, L.K., Haile, R.W., Ingles, S.A., Coetzee, G.A., 1999. Vitamin D receptor 3'-untranslated region polymorphisms: lack of effect on mRNA stability. Biochim. Biophys. Acta 1453, 311-320. 
Fang, Y., van Meurs, J.B., Bergink, A.P., Hofman, A., van Duijn, C.M., van Leeuwen, J.P., Pols, H.A., Uitterlinden, A.G., 2003. Cdx-2 polymorphism in the promoter region of the human vitamin $\mathrm{D}$ receptor gene determines susceptibility to fracture in the elderly. J. Bone Miner. Res. $18,1632-1641$.

Faraco, J.H., Morrison, N.A., Baker, A., Shine, J., Frossard, P.M., 1989. ApaI dimorphism at the human vitamin D receptor gene locus. Nucleic Acids Res. 17, 2150.

Ferrari, S., Manen, D., Bonjour, J.P., Slosman, D., Rizzoli, R., 1999. Bone mineral mass and calcium and phosphate metabolism in young men: relationships with vitamin D receptor allelic polymorphisms. J. Clin. Endocrinol. Metab. 84, 2043-2048.

Fleet, J.C., Harris, S.S., Wood, R.J., Dawson-Hughes, B., 1995. The BsmI vitamin D receptor restriction fragment length polymorphism (BB) predicts low bone density in premenopausal black and white women. J. Bone Miner. Res. 10, 985-990.

Gabriel, S.B., Schaffner, S.F., Nguyen, H., Moore, J.M., Roy, J., Blumenstiel, B., Higgins, J., DeFelice, M., Lochner, A., Faggart, M., Liu-Cordero, S.N., Rotimi, C., Adeyemo, A., Cooper, R., Ward, R., Lander, E.S., Daly, M.J., Altshuler, D., 2002. The structure of haplotype blocks in the human genome. Science 296, 2225-2229.

Garnero, P., Borel, O., Sornay-Rendu, E., Delmas, P.D., 1995. Vitamin D receptor gene polymorphisms do not predict bone turnover and bone mass in healthy premenopausal women. J. Bone Miner. Res. 10, $1283-1288$.

Graafmans, W.C., Lips, P., Ooms, M.E., van Leeuwen, J.P., Pols, H.A., Uitterlinden, A.G., 1997. The effect of vitamin D supplementation on the bone mineral density of the femoral neck is associated with vitamin D receptor genotype. J. Bone Miner. Res. 12, 1241-1245.

Gross, C., Eccleshall, T.R., Malloy, P.J., Villa, M.L., Marcus, R., Feldman, D., 1996. The presence of a polymorphism at the translation initiation site of the vitamin D receptor gene is associated with low bone mineral density in postmenopausal Mexican-American women. J. Bone Miner. Res. 11, 1850-1855.

Gross, C., Krishnan, A.V., Malloy, P.J., Eccleshall, T.R., Zhao, X.Y., Feldman, D., 1998a. The vitamin D receptor gene start codon polymorphism: a functional analysis of FokI variants. J. Bone Miner. Res. 13, $1691-1699$.

Gross, C., Musiol, I.M., Eccleshall, T.R., Malloy, P.J., Feldman, D., 1998b. Vitamin D receptor gene polymorphisms: analysis of ligand binding and hormone responsiveness in cultured skin fibroblasts. Biochem. Biophys. Res. Commun. 242, 467-473.

Hansen, T.S., Abrahamsen, B., Henriksen, F.L., Hermann, A.P., Jensen, L.B., Horder, M., Gram, J., 1998. Vitamin D receptor alleles do not predict bone mineral density or bone loss in Danish perimenopausal women. Bone 22, 571-575.

Haussler, M.R., Whitfield, G.K., Haussler, C.A., Hsieh, J.C., Thompson, P.D., Selznick, S.H., Dominguez, C.E., Jurutka, P.W., 1998. The nuclear vitamin D receptor: biological and molecular regulatory properties revealed. J. Bone Miner. Res. 13, 325-349.

Ho, Y.V., Briganti, E.M., Duan, Y., Buchanan, R., Hall, S., Seeman, E., 1999. Polymorphism of the vitamin D receptor gene and corticosteroidrelated osteoporosis. Osteoporos. Int. 9, 134-138.

Howard, G., Nguyen, T., Morrison, N., Watanabe, T., Sambrook, P., Eisman, J., Kelly, P.J., 1995. Genetic influences on bone density: physiological correlates of vitamin D receptor gene alleles in premenopausal women. J. Clin. Endocrinol. Metab. 80, 2800-2805.

Huang, M.C., Seyer, J.M., Thompson, J.P., Spinella, D.G., Cheah, K.S., Kang, A.H., 1991. Genomic organization of the human procollagen alpha 1(II) collagen gene. Eur. J. Biochem. 195, 593-600.

Ingles, S.A., Haile, R.W., Henderson, B.E., Kolonel, L.N., Nakaichi, G., Shi, C.Y., Yu, M.C., Ross, R.K., Coetzee, G.A., 1997. Strength of linkage disequilibrium between two vitamin D receptor markers in five ethnic groups: implications for association studies. Cancer Epidemiol. Biomark. Prev. 6, 93-98.

Jurutka, P.W., Remus, L.S., Whitfield, G.K., Thompson, P.D., Hsieh, J.C., Zitzer, H., Tavakkoli, P., Galligan, M.A., Dang, H.T., Haussler, C.A.,
Haussler, M.R., 2000. The polymorphic $\mathrm{N}$ terminus in human vitamin D receptor isoforms influences transcriptional activity by modulating interaction with transcription factor IIB. Mol. Endocrinol. 14, 401-420.

Krall, E.A., Parry, P., Lichter, J.B., Dawson-Hughes, B., 1995. Vitamin D receptor alleles and rates of bone loss: influences of years since menopause and calcium intake. J. Bone Miner. Res. 10, 978-984.

Kroger, H., Mahonen, A., Ryhanen, S., Turunen, A.M., Alhava, E., Maenpaa, P., 1995. Vitamin D receptor genotypes and bone mineral density. Lancet 345, 1238.

Kurabayashi, T., Tomita, M., Matsushita, H., Yahata, T., Honda, A., Takakuwa, K., Tanaka, K., 1999. Association of vitamin D and estrogen receptor gene polymorphism with the effect of hormone replacement therapy on bone mineral density in Japanese women. Am. J. Obstet. Gynecol. 180, 1115-1120.

Labuda, M., Fujiwara, T.M., Ross, M.V., Morgan, K., Garcia-Heras, J., Ledbetter, D.H., Hughes, M.R., Glorieux, F.H., 1992. Two hereditary defects related to vitamin D metabolism map to the same region of human chromosome 12q13-14. J. Bone Miner. Res. 7, $1447-1453$.

Marc, J., Prezelj, J., Komel, R., Kocijancic, A., 1999. VDR genotype and response to etidronate therapy in late postmenopausal women. Osteoporos. Int. 10, 303-306

Matsuyama, T., Ishii, S., Tokita, A., Yabuta, K., Yamamori, S., Morrison, N.A., Eisman, J.A., 1995. Vitamin D receptor genotypes and bone mineral density. Lancet 345, 1238-1239.

McClure, L., Eccleshall, T.R., Gross, C., Villa, M.L., Lin, N., Ramaswamy, V., Kohlmeier, L., Kelsey, J.L., Marcus, R., Feldman, D., 1997. Vitamin $\mathrm{D}$ receptor polymorphisms, bone mineral density, and bone metabolism in postmenopausal Mexican-American women. J. Bone Miner. Res. 12, $234-240$

Miyamoto, K., Kesterson, R.A., Yamamoto, H., Taketani, Y., Nishiwaki, E., Tatsumi, S., Inoue, Y., Morita, K., Takeda, E., Pike, J.W., 1997. Structural organization of the human vitamin D receptor chromosomal gene and its promoter. Mol. Endocrinol. 11, 1165-1179.

Mocharla, H., Butch, A.W., Pappas, A.A., Flick, J.T., Weinstein, R.S., De Togni, P., Jilka, R.L., Roberson, P.K., Parfitt, A.M., Manolagas, S.C., 1997. Quantification of vitamin D receptor mRNA by competitive polymerase chain reaction in PBMC: lack of correspondence with common allelic variants. J. Bone Miner. Res. 12, 726-733.

Morrison, N.A., Yeoman, R., Kelly, P.J., Eisman, J.A., 1992. Contribution of trans-acting factor alleles to normal physiological variability: vitamin D receptor gene polymorphism and circulating osteocalcin. Proc. Natl. Acad. Sci. U. S. A. 89, 6665-6669.

Morrison, N.A., Qi, J.C., Tokita, A., Kelly, P.J., Crofts, L., Nguyen, T.V., Sambrook, P.N., Eisman, J.A., 1994. Prediction of bone density from vitamin D receptor alleles. Nature 367, 284-287.

Ohtera, K., Ishii, S., Matsuyama, T., 2001. Influence of the vitamin D receptor alleles on human osteoblast-like cells. J. Bone Jt. Surg. Br. $83,134-138$.

Rauch, F., Radermacher, A., Danz, A., Schiedermaier, U., Golucke, A., Michalk, D., Schonau, E., 1997. Vitamin D receptor genotypes and changes of bone density in physically active German women with high calcium intake. Exp. Clin. Endocrinol. Diabetes 105, 103-108.

Risch, N., Merikangas, K., 1996. The future of genetic studies of complex human diseases. Science 273, 1516-1517.

Saijo, T., Naito, E., Ito, M., Takeda, E., Hashimoto, T., Kuroda, Y., 1991. Therapeutic effect of sodium dichloroacetate on visual and auditory hallucinations in a patient with MELAS. Neuropediatrics 22, 166-167.

Schaaf, M.J., Cidlowski, J.A., 2002. AUUUA motifs in the $3^{\prime}$ UTR of human glucocorticoid receptor alpha and beta mRNA destabilize mRNA and decrease receptor protein expression. Steroids 67, 627-636.

Sowers, M., Willing, M., Burns, T., Deschenes, S., Hollis, B., Crutchfield, M., Jannausch, M., 1999. Genetic markers, bone mineral density, and serum osteocalcin levels. J. Bone Miner. Res. 14, 1411-1419.

Sturzenbecker, L., Scardaville, B., Kratzeisen, C., Katz, M., Abarzua, P., McLane, J., 1994. Isolation and analysis of cDNA endocing a naturally 
occurring truncated form of the human vitamin D receptor. In: Bouilon, R., Norman, A., Thomasset, M. (Eds.), Vitamin D: A Pluripotent Steroid Hormone: Structural Studies, Molecular Endocrinology and Clinical Applications. Walter de Gruyter, Berlin, pp. 253-257.

Takahashi, E., Hori, T., Sutherland, G.R., 1990. Mapping of the human type II collagen gene (COL2A1) proximal to fra(12) (q13.1) by nonisotopic in situ hybridization. Cytogenet. Cell Genet. 54, 84-85.

Taymans, S.E., Pack, S., Pak, E., Orban, Z., Barsony, J., Zhuang, Z., Stratakis, C.A., 1999. The human vitamin D receptor gene (VDR) is localized to region $12 \mathrm{cen}-\mathrm{q} 12$ by fluorescent in situ hybridization and radiation hybrid mapping: genetic and physical VDR map. J. Bone Miner. Res. 14, 1163-1166.

The International HapMap Consortium, 2003. The International Hapmap Project. Nature 426, 789-796.

Tokita, A., Matsumoto, H., Morrison, N.A., Tawa, T., Miura, Y., Fukamauchi, K., Mitsuhashi, N., Irimoto, M., Yamamori, S., Miura, M., Watanabe, T., Kuwabara, Y., Yabuta, K., Eisman, J.A., 1996. Vitamin D receptor alleles, bone mineral density and turnover in premenopausal Japanese women. J. Bone Miner. Res. 11, 1003-1009.

Tsai, K.S., Hsu, S.H., Cheng, W.C., Chen, C.K., Chieng, P.U., Pan, W.H., 1996. Bone mineral density and bone markers in relation to vitamin D receptor gene polymorphisms in Chinese men and women. Bone 19, $513-518$.

Uitterlinden, A.G., Pols, H.A., Burger, H., Huang, Q., Van Daele, P.L., van Duijn, C.M., Hofman, A., Birkenhager, J.C., van Leeuwen, J.P., 1996. A large-scale population-based study of the association of vitamin D receptor gene polymorphisms with bone mineral density. J. Bone Miner. Res. $11,1241-1248$.
Verbeek, W., Gombart, A.F., Shiohara, M., Campbell, M., Koeffler, H.P., 1997. Vitamin D receptor: no evidence for allele-specific mRNA stability in cells which are heterozygous for the TaqI restriction enzyme polymorphism. Biochem. Biophys. Res. Commun. 238, 77-80.

Wall, J.D., Pritchard, J.K., 2003. Haplotype blocks and linkage disequilibrium in the human genome. Nat. Rev. Genet. 4, 587-597.

Whitfield, G.K., Remus, L.S., Jurutka, P.W., Zitzer, H., Oza, A.K., Dang, H.T., Haussler, C.A., Galligan, M.A., Thatcher, M.L., Encinas, D.C., Haussler, M.R., 2001. Functionally relevant polymorphisms in the human nuclear vitamin D receptor gene. Mol. Cell. Endocrinol. 177, $145-159$.

Willing, M., Sowers, M., Aron, D., Clark, M.K., Burns, T., Bunten, C., Crutchfield, M., D’Agostino, D., Jannausch, M., 1998. Bone mineral density and its change in white women: estrogen and vitamin $\mathrm{D}$ receptor genotypes and their interaction. J. Bone Miner. Res. 13, 695-705.

Yamagata, M., Nakajima, S., Tokita, A., Sakai, N., Yanagihara, I., Yabuta, K., Ozono, K., 1999. Analysis of the stable levels of messenger RNA derived from different polymorphic alleles in the vitamin D receptor gene. J. Bone Miner. Metab. 17, 164-170.

Yamamoto, H., Miyamoto, K., Li, B., Taketani, Y., Kitano, M., Inoue, Y., Morita, K., Pike, J.W., Takeda, E., 1999. The caudal-related homeodomain protein $\mathrm{Cdx}-2$ regulates vitamin $\mathrm{D}$ receptor gene expression in the small intestine. J. Bone Miner. Res. 14, 240-247.

Ye, W.Z., Reis, A.F., Velho, G., 2000. Identification of a novel Tru91 polymorphism in the human vitamin D receptor gene. J. Hum. Genet. $45,56-57$.

Zmuda, J.M., Cauley, J.A., Ferrell, R.E., 2000. Molecular epidemiology of vitamin D receptor gene variants. Epidemiol. Rev. 22, 203-217. 